\title{
Types and intensity of postdivorce conflicts, the exercise of coparenting and its consequences on children
}

\author{
Patricia Jiménez-García, Lourdes Contreras*y M.Carmen Cano-Lozano \\ Universidad de Jaén
}

- Recibido: $05-11-2018$. Aceptado: $16-11-2018$

\begin{abstract}
Marital breakup is considered as one of the most stressful events in the life of any family, being possible to appear numerous conflicts until reaching the new family restructuring. It has been previously noted that negative effects of divorce on children are mainly determined by the interparental conflict. Therefore, this study was aimed to identify the types and intensity of postdivorce conflicts, along with the exercise of coparenting after the divorce, examining their effects on children's emotional, behavioural and academic adjustment. In this study, a total of 317 fields of the Family Meeting Point of Jaén (Spain), from 2009 to 2016, were analysed. From these fields, children's emotional, behavioural and academic variables were examined, together with interparental variables. The results showed a higher number of cases of children with emotional, behavioural, and academic maladjustment when there are financial and custody postdivorce conflicts, when there is a moderate and high intensity of parental conflicts after the divorce, and in absence of the exercise of postdivorce coparenting between the parents. This study highlights the need to implement prevention and intervention programs with the parents to ensure an appropriate management of postdivorce conflicts.
\end{abstract}

KEYWORDS: Divorce; Types of conflicts; Intensity of conflicts; Coparenting.

Tipos e intensidad de los conflictos postdivorcio, ejercicio de la coparentalidad y sus consecuencias en los hijos

RESUMEN: La ruptura conyugal se considera uno de los eventos más estresantes en la vida de cualquier familia, pudiéndose manifestar numerosos conflictos hasta alcanzar la nueva reestructuración familiar. Se ha señalado que los efectos negativos del divorcio en los hijos están determinados principalmente por el conflicto interparental. Por tanto, el objetivo de este estudio fue identificar los tipos e intensidad de los conflictos que se producen tras el divorcio, así como el ejercicio de la coparentalidad, examinando sus efectos en el ajuste emocional, conductual y escolar de los hijos. En este estudio se han analizado 317 expedientes del Punto de Encuentro Familiar de Jaén (España), desde 2009 a 2016. Se han analizado variables psicoemocionales, conductuales, y escolares de los hijos, así como variables interparentales. Los resultados indicaron un mayor número de casos de menores con desajustes emocionales, conductuales y escolares cuando existen conflictos post-divorcio de tipo económico y de custodia, cuando existe intensidad moderada y alta de conflictos parentales tras la ruptura y en ausencia del ejercicio de la coparentalidad post-divorcio entre los progenitores. Con este estudio, se plantea la necesidad de implementar programas de prevención e intervención con los progenitores para garantizar una adecuada gestión de los conflictos post-divorcio.

PALABRAS CLAVE: Divorcio; Tipos de conflicto; Intensidad de conflictos; Coparentalidad.

Research into divorce and its consequences has been a topic of particular interest to the scientific community, both nationally and internationally, and continues to draw attention

*Correspondence: Lourdes Contreras

Universidad de Jaén

CP: 23071, Jaén, España.

E-mail: Imcontre@ujaen.es

(c) 2018 Sociedad Universitaria de Investigación en Psicología y Salud. Publicado por Consejo General de Colegios Oficiales de Psicólogos, España. Este es un artículo Open Access
bajo la CC BY-NC-ND licencia (http://creativecommons.org/licencias/by-nc-nd/4.0/). due to the increasing numbers of divorces recorded each year. In Spain specifically, there has been a significant rise in recent decades, from a divorce rate of 0.6 per 1,000 inhabitants in 2000 to a rate of 2.2 per 1,000 in 2015 (Eurostat, 2017).

The impacts of a parental split on children are well-documented (see the review by Fagan \& Churchill, 2012, for example), emphasising the physical and psycho-emotional adjustment 
required (Corrás et al., 2017; Martiñón et al., 2017). A recent study undertaken among the Spanish population shows that the separation of parents has a negative impact on children and teenagers, giving rise to poorer psychological, emotional, social and academic adjustment (Seijo, Fariña, Corrás, Novo, \& Arce, 2016).

However, the impact of divorce is not the same in all cases (Overbeek et al., 2006). Indeed, trends in research into the impacts of divorce on children have been evolving in recent years, with a more complex and less linear perspective on the topic adopted. In this way, it is suggested that the negative impacts on children do not come from the divorce itself, but instead from other concurrent or mediating variables (Rappaport, 2013), such as the adaptation of parents to the divorce (Yárnoz-Yaben, Comino, \& Garmendia, 2012) or interparental conflict (Contreras \& Cano-Lozano, 2016; Cutrín, Gómez-Fraguela, Maneiro, \& Sobral, 2017; Mclntosh \& Long, 2005; Guillén, Roth, Alfaro, \& Fernández, 2015; Landsford, 2009; Overbeek et al., 2006; Zemp, Bodenmann, \& Cummings, 2016). More specifically, Yárnoz-Yaben et al. (2012) found that the behavioural problems observed in children following divorce (both externalising and internalising) were negatively correlated with the post-divorce adaptation of their parents. More recently, Arkes (2015) undertook a study using data from the National Longitudinal Survey of Youth of 1979 and the Child and Young Adult Survey. The author discovered that the effects of divorce on the behavioural and academic adjustment (behavioural problems) of children begin before the divorce itself takes place (2-4 years earlier), potentially due to existing parental conflict, and that these effects continue for at least two years after the divorce, although they tend to diminish over time.

In this sense, it is widely acknowledged that marital breakdown is considered to be one of the most stressful events in the life of any family, with numerous conflicts likely to arise before a new family structure is established (Amato, 2000). On many occasions, separations and divorces which were originally resolved amicably develop over time into a legal process, due largely to the dynamic nature of interpersonal relationships. In particular, in splits which result in post- divorce conflict, interparental disputes frequently continue over long periods of time, while other family members are immersed in this traumatic situation (Arch, 2010; Kelly, 2003; Mclntosh \& Long, 2005) Some authors suggest that divorce is inherently conflictual, as conflict represents an intrinsic part of the process of the end of a relationship and of the emotional separation of a couple (Arce, Fariña, \& Seijo, 2005; YárnozYaben, 2010).

Although the types of conflict present are not always the same, nor do they all provoke the same impact, the most common issues are related to the distribution of assets, the residence of children, care and custody, visiting arrangements and alimony (Arce et al., 2005). In this regard, Yárnoz-Yaben (2010) summarises the approaches adopted by Hopper (2001) and Markham, Ganong, \& Coleman (2007) to the different types of conflict which occur following divorce: symbolic conflicts, regarding financial matters, custody (relating both to the concepts of care and custody of children, as well as the regulation of parent-child relationships), decisions to be taken with regard to children (disagreements between parents regarding the different areas of children's lives) and conflicts deriving from role redefinition. Concerning symbolic conflicts, Yárnoz-Yaben (2013) suggests that the profound value often accorded to marriage, including the idea that it is for life, creates the problem of rediscovering meaning in the demise of the couple. As such, an intense moral preoccupation may arise in the form of feelings of betrayal, shame, guilt and stigma in the context of divorce and its symbolic value (Hopper, 2001). With regard to the redefinition of roles, authors such as Madden-Derdich, Leornard, \& Cristopher (1999) and Madden-Derdich \& Leonard (2000) suggest that a significant source of conflict following divorce is related to the difficult task of renouncing the marital role while finding effective ways of performing a parental role. Therefore, this type of conflict arises when parents are unable to establish new relationship patterns and to negotiate the limits which differentiate their role as parents from their relationship as ex-partners.

However, there are very few studies on the most common types of conflict and their 
impact on children. Some authors state that following divorce, it is common for some families to continue experiencing conflict relating to financial matters, coparenting and visiting arrangements (Chen \& George, 2005). Bonach (2005) undertook a study of 135 participants who were undergoing processes of separation and/or divorce and who had underage children, finding that the most common points of conflict were related to visiting arrangements for children and financial matters. Indeed, it has been found that conflicts relating to the pattern of contact and relationships to be established between parents and children following separation or divorce are among the most difficult to resolve and have a greater impact on the family, particularly on children (Galatzer-Levy \& Krauss, 1999).

The literature on the topic also indicates that the level and intensity of conflict between parents during marriage is an indicator of postdivorce hostility and the most decisive factor in the post-divorce adjustment of children (see review by Mitcham-Smith \& Henry, 2007). As Amato (2010) points out, other studies suggest that the consequences of divorce for children depend on the quality of intra-family relationships prior to the divorce. For example, in situations in which divorce represents an end to a conflictual marriage, few changes are observed in children, or improvements in their wellbeing may even be noted (Amato, 2000). The children of divorced parents who escape exposure to interparental conflict once cohabitation ceases may experience a better adjustment in the long term than those whose parents remain in marriages with high levels of conflict (Landsford, 2009). On the other hand, many couples who divorce due to the high levels of conflict between them maintain this degree of conflict after the divorce, with clear negative repercussions for their children's adjustment (Chen \& George, 2005).

Some authors indicate that certain postdivorce relationships are so conflictual that they may even become destructive (Davies et al., 2002), representing the most negative aspect of this process, marked by aggression, hostility and disparagement, causing a prolongation of the conflict and rendering it harder to resolve (López-Larrosa, Sánchez-Souto, \& Mendiri, 2012). In this sense, highly conflictual post- divorce relationships are those in which there are a large number of recurrent legal disputes, verbal and/or physical aggression, with a high degree of anger and mistrust, difficulties in focusing on the needs of children as separate from the needs of the parents, and problems with coparenting and communicating about children following the divorce (Bacon \& McKenzie, 2004). Similarly, Yárnoz-Yaben et al. (2012) found that the children of separated/divorced parents with above average levels of conflict showed a clear tendency to display more internalising problems.

Closely linked to this issue is the practice of coparenting following divorce, which has been demonstrated to be inversely correlated with conflict between parents (Markham \& Coleman, 2012). A coparenting relationship may be defined as "one in which the two parents interact positively, cooperate with one another and maintain a relationship of mutual support focused primarily on the parenting of their children, both playing an active role in their children's lives" (Ahrons, 1981, cited in YárnozYaben, 2010, p. 296-297). Therefore, it has been shown that children will adapt to the end of their parents' relationship with a lesser sense of loss if both parents are actively involved in their lives following the divorce (Morgado, 2010). This involvement appears to be mediated by the quality of the post-divorce relationship between parents (Choi \& Pyun, 2014). Moreover, a recent meta-analysis conducted by Adamsons \& Johnston (2013) found that the involvement of non-custodial parents in the different areas of their children's lives was strongly associated with good academic, social, emotional and behavioural adjustment.

Thus, while there is abundant literature on the consequences of divorce for children, as well as on the impact of post-divorce interparental conflict, there is a lack of studies which analyse the differential effect of different types of postdivorce conflict on the emotional, behavioural and academic adjustment of children. As such, it is important to explore further these post-divorce dynamics and their influence on children's adaptation. As a result, the aim of this study is to identify the types and intensity of conflicts arising after divorce, as well as the practice of coparenting, examining their impact 
on the emotional, behavioural and educational adjustment of children. An ideal context in which to examine post-divorce conflicts are the Family Meeting Points, which are public and specialized services, with a professional multidisciplinary team, to guarantee compliance with the agreed visiting arrangements established by court ruling. These temporary services are used when family relationships are difficult to maintain or take place in an environment of parental conflict after a separation/divorce process, and they are intended to serve as a neutral space to guarantee the essential right of minors to bond with their parents and relatives, following a separation, divorce or other instances of disruption to family cohabitation. It is in these spaces that this research was conducted.

On the basis of the existing literature, the following hypotheses are advanced in this study: although the differential impact of the different types of post-divorce conflict on children have not been specifically studied, it has been noted that the most difficult post-divorce conflicts to resolve and those which have a greater impact on the family, particularly upon children, are related to the visiting arrangements of the children (Galatzer-Levy \& Krauss, 1999). In this manner, a larger number of cases of impacted emotional, behavioural and educational adjustment may be expected in this type of conflict compared with other types of conflict (Hypothesis 1). Besides, when there are higher levels of post-divorce conflict between parents, there will be a larger number of cases of children affected emotionally, behaviourally and educationally, in comparison with lower levels of conflict (Chen \& George, 2005; Yárnoz-Yaben et al., 2012) (Hypothesis 2). A larger number of cases of emotionally, behaviourally and educationally affected children may also be expected in the absence of coparenting between parents, in comparison with the presence of coparenting (Adamsons \& Jonhston, 2013; Morgado, 2010) (Hypothesis $3)$. As a result, it is considered that conflicts surrounding care and custody, high levels of conflict and the absence of coparenting will be the best predictors of emotional, behavioural and educational impact on children (Hypothesis 4).

\section{METHOD}

\section{-PROTOCOLS}

A total of 317 legal files from the Family Meeting Point of Jaén, a province in the south of Spain, corresponding to the period from 2009 to 2016 were analysed. This files refer exclusively to families in separation/divorce processes. The sample included 449 children (52.3\% girls y $47.7 \%$ boys, $M_{\text {age }}=6.54, \mathrm{SD}=$ 1.16). From them, $45.2 \%$ were younger than 6 years old, the $39.4 \%$ were aged between 6 and 10 years, the $12.0 \%$ were aged between 11 and 15 years and $3.3 \%$ were older of 15 years. From the legal files analysed, the $90.4 \%$ of women had the guardianship of their children, whereas the $9.4 \%$ of fathers and the $0.2 \%$ of grand parents had the guardianship. Regarding the number of children, $60.7 \%$ of these families had a single child, $30.2 \%$ had two children and $9.1 \%$ had three child or more.

\section{-DESIGN AND PROCEDURE}

In this ex post facto study (Montero \& León, 2007), the information included in the legal files from the Family Meeting Service of Jaén has been analysed, together with the initial psychological assessment carried out by the Psychosocial Team who was working at this Service. These files contained the following documents: forensic psychological reports, interviews with the parents, psychosocial assessment carried out by the Psychosocial Team (they weekly determine the psychological state of the children and the parents' ability to solve conflicts), school reports, which parent has the custody, number of children, and finally, ages and sexes of the children who attend to this Service.

To ensure the inter-rater reliability, a second researcher conducted a review of the $10 \%$ of the judicial files, randomly selected. After the second review, some of the variables that did not get the maximum agreement between researchers were removed. Thus, the variables finally included had a 100\% of agreement between researchers. Although in general the legal files contained information about all the 
variables, some of them lacked much of the information. Consequently, some values were missing from the results.

Given the special nature of the participants, authorization from both the Justice Service of Jaén and the General Direction of Gender Violence and Victims Assistance of the Junta de Andalucía to examine the legal files was previously requested. Furthermore, the collaboration of the Psychosocial Team of the Family Meeting Point was also requested. To ensure confidentiality, an identification code was assigned to each legal file.

Three grouping variables have been selected. The first variable is the type of conflicts generated after the divorce/separation of the parents, which were coded according to the classification made by Yárnoz-Yaben (2010) from the approaches adopted by Hopper (2001) and Markhnam et al. (2007): symbolic conflict, financial, custody, decisions on children, and redefinition of roles conflicts. The second grouping variable was the intensity of the conflicts between parents (low, moderate, high): low intensity refers to those cases with one judicial proceedings against the ex-partner, moderate intensity are those cases with 2-3 judicial proceedings against the ex-partner, and high intensity are those with more than 3 judicial proceedings against the ex-partner. The third grouping variable was the parents' exercise of coparenting (yes, no). This variable was determined by the presence of both communication and cooperation between the two parents regarding aspects of the life and rearing of their children. Only in case these two elements were present, the exercise of coparenting was considered.

Regarding the children's characteristics, emotional, behavioural, and academic variables were analysed, coded as yes/no. Concretely, regarding emotional variables, the presence of sadness and crying, low self-esteem, anxiety, anger and separation anxiety were examined. Among the behavioural variables, the presence of disobedience, aggressiveness, and self-harm were analysed. Respecting academic variables, the decrease of academic performance was explored. This information was obtained through semi-structured interviews and other documentary reports.

\section{- DATA ANALYSIS}

First, descriptive analyses including frequency and percentage of all the variables were made. To explore statistically significant differences among the proportions of the frequencies of variables according to the type and intensity of the conflict, a Kruskal-Wallis test was used. Next, to examine significant differences among pairs of groups, post hoc analyses with the Mann-Whitney $U$ test were made, by applying the Bonferroni correction ( $p=.01$ for the types of conflict and $p=.01$ for intensity of conflict). To analyse significant differences in the proportion of frequencies according to the exercise of coparenting, a Mann-Whitney $U$ test was used. Finally, to examine the relationship between types of conflict, intensity of conflict, and the exercise of coparenting, contingency analyses through the index of association Phi $(\varphi)$ was made.

Then, with the aim to predict differences by the type of conflict, intensity of conflict, and the exercise of coparenting on the emotional, behavioural, and academic impact, three logistic regressions with forward stepwise method were performed. It was considered that there was behavioural impact on children when there was aggressiveness, disobedience, or self-harm behaviours. It was considered that there was emotional impact on children in case of sadness and crying, low self-esteem, anxiety, anger, or separation anxiety. The presence of impact was given a value of 1 in the parameter-coding scheme, whereas the absence of impact was given a value of 0 . The significance of model parameters was performed by using the Wald test, accepting a significance level $\alpha<.05$.

\section{RESULTS}

\section{-TYPES OF CONFLICTS}

Kruskal-Wallis test showed significant differences according to the type of conflict in the proportion of cases of sadness and crying $\chi^{2}(4, N=373)=10.58, p<.05, \varphi=.17$, aggressiveness, $\chi^{2}(4, N=372)=36.12, p<$ $.001, \varphi=.31$, disobedience $\chi^{2}(4, N=372)=$ $26.68, p<.001, \varphi=.27$, self-harm behaviours $\chi^{2}(4, N=372)=42.36, p<.001, \varphi=.34$, 
anxiety $\chi^{2}(4, N=372)=11.2, p<.05, \varphi=$ .17 , anger $\chi^{2}(4, N=372)=27.00, p<.001$, $\varphi=.27$, and decrease of academic performance $\chi^{2}(4, N=290)=14.25, p<.01$, $\varphi=.22$. Regarding the aggressiveness variable, post hoc analyses revealed a higher proportion of cases in the financial conflict compared to symbolic conflicts, decisions on children conflicts, and redefinition of roles conflicts. Furthermore, a higher proportion of cases of aggressiveness in custody conflicts in comparison with redefinition of roles conflicts were shown.

Post hoc analyses also indicated a higher proportion of cases of disobedience in the financial conflicts when compared to symbolic,

Table 1

Distribution of variables according to the types of conflicts

\begin{tabular}{|c|c|c|c|c|c|c|}
\hline \multicolumn{6}{|c|}{ Types of conflicts } & \multirow[t]{2}{*}{$\chi^{2}$} \\
\hline & $\begin{array}{c}\text { Symbolic } \\
(\%)\end{array}$ & $\begin{array}{c}\text { Financial } \\
(\%)\end{array}$ & $\begin{array}{c}\text { Custody } \\
\text { (\%) }\end{array}$ & $\begin{array}{l}\text { D.Child } \\
\text { (\%) }\end{array}$ & $\begin{array}{c}\text { Redef. roles } \\
(\%)\end{array}$ & \\
\hline Sadness-Crying & $N(97)$ & $N(62)$ & $N(48)$ & $N(45)$ & $N(119)$ & $10.58^{* *}$ \\
\hline Yes & 51.5 & 58.1 & 58.3 & 42.2 & 37.8 & \\
\hline No & 48.5 & 41.9 & 41.7 & 57.8 & 62.2 & \\
\hline Aggressiveness & $N(97)$ & $N(62)$ & $N(48)$ & $N(44)$ & $N(119)$ & $36.12^{*}$ \\
\hline Yes & 21.6 & 50.0 & 31.3 & 15.9 & 11.8 & \\
\hline No & 78.4 & 50.0 & 68.8 & 84.1 & 88.2 & \\
\hline Disobedience & $N(97)$ & $N(62)$ & $N(48)$ & $N(44)$ & $N(119)$ & $26.68 *$ \\
\hline Yes & 34.0 & 56.5 & 43.8 & 18.2 & 23.5 & \\
\hline No & 66.0 & 43.5 & 56.3 & 81.8 & 76.5 & \\
\hline Low self-esteem & $N(96)$ & $N(61)$ & $N(48)$ & $N(44)$ & $N(119)$ & 5.26 \\
\hline Yes & 38.5 & 44.3 & 39.6 & 38.6 & 28.6 & \\
\hline No & 61.5 & 55.7 & 60.4 & 61.4 & 71.4 & \\
\hline Self-harm behaviours & $N(97)$ & $N(62)$ & $N(48)$ & $N(44)$ & $N(119)$ & $42.36^{*}$ \\
\hline Yes & 4.1 & 30.6 & 14.6 & 4.5 & 3.4 & \\
\hline No & 95.9 & 69.4 & 85.4 & 95.5 & 96.6 & \\
\hline Anxiety & $N(97)$ & $N(62)$ & $N(48)$ & $N(44)$ & $N(119)$ & 11.20 ** \\
\hline Yes & 39.2 & 41.9 & 39.6 & 27.3 & 22.7 & \\
\hline No & 60.8 & 58.1 & 60.4 & 72.7 & 77.3 & \\
\hline Anger & $N(97)$ & $N(62)$ & $N(48)$ & $N(44)$ & $N(119)$ & 27.00 * \\
\hline Yes & 20.6 & 43.5 & 31.3 & 15.9 & 11.8 & \\
\hline No & 79.4 & 56.5 & 68.8 & 84.1 & 88.2 & \\
\hline Separation anxiety & $N(97)$ & $N(62)$ & $N(48)$ & $N(44)$ & $N(119)$ & 1.10 \\
\hline Yes & 19.6 & 25.8 & 20.8 & 20.5 & 23.5 & \\
\hline No & 80.4 & 74.2 & 79.2 & 79.5 & 76.5 & \\
\hline $\begin{array}{l}\text { Decrease of academic } \\
\text { performance }\end{array}$ & $N(82)$ & $N(50)$ & $N(36)$ & $N(35)$ & $N(85)$ & $14.25^{\star}$ \\
\hline Yes & 51.2 & 66.0 & 50.0 & 40.0 & 34.1 & \\
\hline No & 48.8 & 34.0 & 50.0 & 60.0 & 65.9 & \\
\hline
\end{tabular}


decisions on children and redefinition of roles conflicts. Furthermore, a higher proportion of cases of disobedience in custody conflicts in comparison with redefinition of roles conflicts and decisions on children conflicts were shown.

Regarding self-harm behaviours and anger, results revealed a higher proportion of cases in financial conflicts when compared to symbolic, decisions on children and redefinition of roles conflicts, and also in custody conflicts in comparison with redefinition of roles conflicts.

With regard to sadness and crying and decrease of academic performance variables, a higher proportion of cases in financial conflicts when compared to redefinition of roles conflicts were shown.
Regarding the anxiety variable, results revealed a higher proportion of cases in redefinition of roles conflicts when compared to symbolic conflicts, and also in financial conflicts in comparison with redefinition of roles conflicts.

\section{- INTENSITY OF THE CONFLICT}

Results indicated significant differences according to the intensity of the conflict in the proportion of cases of sadness and crying $\chi^{2}(2, N=322)=21.61, p<.001, \varphi=.24$, aggressiveness $\chi^{2}(2, N=321)=43.51, p<$ $.001, \varphi=.34$, disobedience $\chi^{2}(2, N=321)$ $=35.94, p<.001, \varphi=.31$, low self-esteem $\chi^{2}(2, N=320)=37.97, p<.001, \varphi=.32$,

Table 2

Distribution of variables according to the intensity of the conflicts

\begin{tabular}{|c|c|c|c|c|}
\hline & \multicolumn{3}{|c|}{ Intensity of the Conflicts } & \multirow[t]{2}{*}{$\chi^{2}$} \\
\hline & Low \% & Moderate \% & High \% & \\
\hline Sadness-Crying & $N(102)$ & $N(166)$ & $N(104)$ & $21.61^{*}$ \\
\hline Yes & 29.4 & 51.8 & 39.4 & \\
\hline No & 70.6 & 48.2 & 60.6 & \\
\hline Aggressiveness & $N(102)$ & $N(166)$ & $N(103)$ & $43.51^{*}$ \\
\hline Yes & 6.9 & 21.1 & 45.6 & \\
\hline No & 93.1 & 78.9 & 52.8 & \\
\hline Disobedience & $N(102)$ & $N(166)$ & $N(103)$ & $35.94^{*}$ \\
\hline Yes & 14.7 & 33.1 & 54.4 & \\
\hline No & 85.3 & 66.9 & 45.6 & \\
\hline Low Self-esteem & $N(102)$ & $N(166)$ & $N(101)$ & $37.97^{*}$ \\
\hline Yes & 16.7 & 36.1 & 58.4 & \\
\hline No & 83.3 & 63.9 & 41.6 & \\
\hline Self-harm behaviours & $N(102)$ & $N(166)$ & $N(103)$ & $19.39 *$ \\
\hline Yes & 1.0 & 9.6 & 19.4 & \\
\hline No & 99.0 & 90.4 & 80.6 & \\
\hline Anxiety & $N(102)$ & $N(166)$ & $N(103)$ & $48.25^{*}$ \\
\hline Yes & 8.8 & 35.5 & 54.4 & \\
\hline No & 91.2 & 64.5 & 45.6 & \\
\hline Anger & $N(102)$ & $N(166)$ & $N(103)$ & $56.70 *$ \\
\hline Yes & 4.9 & 18.1 & 47.6 & \\
\hline No & 95.1 & 81.9 & 52.4 & \\
\hline Separation anxiety & $N(102)$ & $N(166)$ & $N(103)$ & 2.74 \\
\hline Yes & 20.4 & 25.9 & 17.6 & \\
\hline No & 79.6 & 74.1 & 82.4 & \\
\hline $\begin{array}{l}\text { Decrease of academic } \\
\text { performance }\end{array}$ & $N(65)$ & $N(135)$ & $N(89)$ & $56.59 *$ \\
\hline Yes & 20.0 & 40.7 & 78.7 & \\
\hline No & 80.0 & 59.3 & 21.3 & \\
\hline
\end{tabular}


self-harm behaviours $\chi^{2}(2, N=321)=19.39$, $p<.001, \varphi=.23$, anxiety $\chi^{2}(2, N=321)=$ 48.25, $p<.001, \varphi=.36$, anger $\chi^{2}(2, N=$ $321)=56.70, p<.001, \varphi=.39$, and decrease of academic performance $\chi^{2}(2, N=256)=$ 56.59, $p<.001, \varphi=.44$. Concretely, post hoc analyses revealed a higher proportion of cases of aggressiveness, disobedience, low selfesteem, self-harm behaviours, anxiety, anger, and decrease of academic performance in the group of high intensity conflicts, comparing to low and moderate intensity conflicts groups. Regarding sadness and crying, results revealed a higher proportion in high and moderate intensity conflicts groups comparing to low intensity conflicts groups.

\section{- EXERCISE OF COPARENTING}

U de Mann Whitney test showed significant differences according to the exercise of coparenting in sadness and crying $(N=372$, $U=10215.000, z=-4.53, r=-.23, \varphi=$ $-.235, p<.001)$, aggressiveness $(N=371$, $U=10517.000, \varphi=-.250, z=-4.80, p$ $<.001, r=-.25)$, disobedience $(N=371$, $U=10281.000, \varphi=-.241, z=-4.64, p<$ $.001, r=-.24)$, low self-esteem $(N=369$, $U=9821.500, \varphi=-.263, z=-5.04, p<$ $.001, r=-.26)$, self-harm behaviours $(N=371$, $U=12082.000, \varphi=-.186, z=-3.58, p<.001$, $r=-.18)$, anxiety $(N=371, U=9085.500, \varphi=$ $-.324, z=-6.24, p<.001, r=-.32)$, anger $(N$

Table 3

Distribution of variables according to the exercise of coparenting

\begin{tabular}{|c|c|c|c|}
\hline & \multicolumn{2}{|c|}{ Exercise of coparenting } & \multirow[t]{2}{*}{$\chi^{2}$} \\
\hline & Yes (\%) & No (\%) & \\
\hline Sadness-Crying & $N(103)$ & $N(269)$ & $20.58 *$ \\
\hline Yes & 29.1 & 55.4 & \\
\hline No & 70.9 & 44.6 & \\
\hline Aggressivenees & $N(103)$ & $N(268)$ & $23.11^{*}$ \\
\hline Yes & 6.8 & 30.6 & \\
\hline No & 93.2 & 69.4 & \\
\hline Disobedience & $N(103)$ & $N(268)$ & $21.59 *$ \\
\hline Yes & 15.5 & 41.0 & \\
\hline No & 84.5 & 59.0 & \\
\hline Low Self-esteem & $N(103)$ & $N(266)$ & $25.43 *$ \\
\hline Yes & 16.5 & 44.7 & \\
\hline No & 83.5 & 55.3 & \\
\hline Self-harm behaviours & $N(103)$ & $N(268)$ & $12.87 *$ \\
\hline Yes & 1.0 & 86.6 & \\
\hline No & 99.0 & 13.4 & \\
\hline Anxiety & $N(103)$ & $N(268)$ & $39.05^{*}$ \\
\hline Yes & 8.7 & 42.9 & \\
\hline No & 91.3 & 57.1 & \\
\hline Anger & $N(103)$ & $N(268)$ & 25.76 * \\
\hline Yes & 4.9 & 29.5 & \\
\hline No & 95.1 & 70.5 & \\
\hline Separation anxiety & $N(103)$ & $N(268)$ & 1.77 \\
\hline Yes & 17.5 & 23.9 & \\
\hline No & 82.5 & 76.1 & \\
\hline Decrease of academic performance & $N(65)$ & $N(224)$ & $25.88^{*}$ \\
\hline Yes & 20.0 & 55.8 & \\
\hline No & 80.0 & 44.2 & \\
\hline
\end{tabular}


$=371, U=10403.500, \varphi=-.263, z=-5.07$, $p<.001, r=-.26)$, and decrease of academic performance $(N=289, U=4673.500, \varphi=$ $-.299, z=-5.08, p<.001, r=-.30)$. To be precise, a higher proportion of cases of sadness and crying, aggressiveness, disobedience, low self-esteem, self-harm behaviours, anxiety, anger, and decrease of academic performance are shown when there is no exercise of coparenting.

\section{-PREDICTORS OF EMOTIONAL, BEHAVIOURAL, AND ACADEMIC IMPACT}

Three logistic regressions with forward stepwise method were performed to assess the impact of the types of post-divorce conflicts, the intensity of conflict, and the exercise of coparenting on the emotional, behavioural, and academic variables. Regarding the behavioural impact, the intensity of conflict was introduced in the step 1, $\chi^{2}(2, N=449)=42.56, p<$ $.001, R^{2}$ Nagelkerke $=.14$ and correctly classified $80.3 \%$ of the cases. In the step 2, the conflict types were introduced in the model and correctly classified $1.3 \%$ of the cases. Finally, the full model containing the two independent variables was statistically significant for behavioral impact $\chi^{2}(6, N=449)=69.34, p<.001, R^{2}$ Nagelkerke $=.23$, and correctly classified $81.6 \%$ of the cases. However, the exercise of coparenting was not introduced into the regression equation. As shown in Table 4, the independent variables that made a statistically significant contribution to the model were financial conflict, custody conflict, high and moderate intensity of conflict. The strongest predictor of behavioural impact was the high intensity of conflict, recording an odds ratio of 8.65. Concretely, when the parents present a high intensity of conflict, it increases in 8 times the behavioural impact on the children.

Regarding emotional variables, the model only introduced the block of conflict intensity in step 1, excluding from the regression equation the conflict types and the exercise of coparenting independent variables. The step 1 was significant for emotional impact $\chi^{2}(2, N=449)=45.93, p$ $<.001, R^{2}$ Nagelkerke $=.13$, and correctly classified $63.5 \%$ of the cases. The independent variable that made a statistically significant contribution to the model was the high and moderate intensity of conflict.

Finally, in respect of academic impact, the step 1 introduced the intensity of conflict variable and obtained a statistically significant contribution, $\chi^{2}(2, N=449)=58.21, p<.001$, $R^{2}{ }_{\text {Nagelkerke }}=0.25$ and correctly classified a 69.7 $\%$ of cases. The conflict types and the exercise of coparenting independent variables were not included into the regression equation. The independent variables that made a statistically significant contribution to the model were the high and moderate intensity of conflict.

Table 4

Regression of emotional, behavioural and academic impact variables

\begin{tabular}{|l|c|c|c|c|c|c|c|}
\hline & $B$ & SE & Wald & GI & $p$ & OR & $95 \% \mathrm{Cl}$ \\
\hline Behavioural impact & & & & & & & \\
Step 19 & & & & & & & \\
Intensity of the conflict & & & 34.45 & 2 & .000 & & \\
High & 2.34 & .431 & 29.33 & 1 & .000 & 10.33 & {$[4.44-24.04]$} \\
Moderate & 1.33 & .431 & 9.51 & 1 & .002 & 3.78 & {$[1.62-8.80]$} \\
Step 2b & & & & & & & \\
Intensity of the conflict & & & 26.87 & 2 & .00 & & \\
High & 2.16 & .441 & 23.99 & 1 & .00 & 8.65 & {$[3.65-20.53]$} \\
Moderate & 1.27 & .441 & 8.33 & 1 & .004 & 3.57 & {$[1.50-8.47]$} \\
Types of conflicts & & & 25.66 & 4 & .000 & & \\
Symbolic & .701 & .383 & 3.34 & 1 & .068 & 2.01 & {$[.950-4.27]$} \\
Economic & 1.72 & .386 & 19.79 & 1 & .000 & 5.57 & {$[2.61-11.87]$} \\
Custody & .914 & .430 & 4.51 & 1 & .034 & 2.49 & {$[1.07-5.79]$} \\
Decisions on children & -.101 & .503 & .040 & 1 & .841 & .904 & {$[.337-2.42]$} \\
\hline
\end{tabular}


Table 4 (Continuation)

Regression of emotional, behavioural and academic impact variables

\begin{tabular}{|l|c|c|c|c|c|c|c|}
\hline & $B$ & SE & Wald & GI & $p$ & OR & $95 \% \mathrm{Cl}$ \\
\hline Emotional impact & & & & & & & \\
Step 1a & & & & & & & \\
Intensity of the conflict & & & 41.74 & 2 & .000 & & \\
High & 1.78 & .278 & 41.15 & 1 & .000 & 5.95 & {$[3.45-10.27]$} \\
Moderate & 1.02 & .241 & 17.79 & 1 & .000 & 2.76 & {$[1.72-4.43]$} \\
Academic impact & & & & & & & \\
Step 19 & & & & & & & \\
Intensity of the conflict & & & 47.68 & 2 & .000 & & \\
High & 2.66 & .404 & 43.32 & 1 & .000 & 14.32 & {$[6.48-31.62]$} \\
Moderate & 1.01 & .356 & 8.07 & 1 & .005 & 2.75 & {$[1.37-5.53]$} \\
\hline
\end{tabular}

Note. OR: Odds Ratio, Cl: Confidential Interval.

\section{DISCUSSION}

The aim of this study was to analyse the types and intensity of post-divorce conflicts existing between parents, the practice or absence of coparenting, and the way in which these elements can affect children at an emotional, behavioural and educational level.

In line with Hypothesis 1, a larger number of cases of emotional, behavioural and educational impact on children was expected when there were custody conflicts, compared to other types of conflict. The results partially confirm this hypothesis, as a larger number of cases of minors displaying aggressive behaviour, disobedience, self-harm and anger were observed when conflicts concerned not only custody, but also financial matters, compared to other types of conflict. Besides, in the case of financial conflict, more cases of children experiencing sadness and crying, anxiety and a worsening in academic performance were found than in other types of conflict. Previously, Bonach (2005) found that the most frequent conflicts between parents were related to the visiting arrangements of children and to financial matters. It has also been noted that children's wellbeing is influenced by the emotional and financial wellbeing of their parents (García \& Solsona, 2011 ), suggesting that post-divorce financial conflicts or those related to changes of home or school affect the relationship between the child and the noncustodial parent, as well as the frequency of the visits (Amato, 2000). One possible explanation for the impact of financial conflict on children is linked to the fact that the cost of the divorce process itself can imply a financial readjustment, or even a reduction in economic status deriving from this process, in such a way that parents may feel that their financial circumstances are threatened when divorce occurs (Braver, Shapiro, \& Goodman, 2006). This reduced or readjusted economic status can increase stress and emotional distress (Amato, 2000; Dudak, 2013) and, as a result, conflict between parents, with repercussions for the adaptation of children to the divorce (Morgado, 2008). With regard to conflict relating to disputes for custody and visiting arrangements, studies have pointed to the severe impact of this type of conflict on children: some even identify these conflicts as the most difficult to resolve and those generating the greatest anxiety among the whole family, particularly in children (Galatzer-Levy \& Krauss, 1999). As noted by Arch (2010), this type of interparental conflict leads to children being positioned at the very heart of the dispute. On balance, the data obtained by this study points to the need to analyse not only the impact of conflict between parents on children, but also to explore further the differential impact of the different types of post-divorce conflict, an aspect which has until now been overlooked.

On the other hand, with regard to the intensity of conflict (Hypothesis 2), the data in this study reveals that the group displaying a high intensity of post-divorce conflict between parents 
shows a larger number of cases of emotional and behavioural problems among children (sadness and crying, low self-esteem, anxiety, anger, aggression, disobedience, self-harm), as well as a greater number of cases of children with reduced academic performance, compared to those experiencing moderate and low levels of conflict. This data confirms our hypothesis and corroborates the existing literature on the subject. Thus, Chen \& George (2005) emphasise that maintaining high levels of conflict following divorce has negative repercussions on children's adjustment. More specifically, YárnozYaben et al. (2012) found that the children of separated/divorced parents with above average levels of conflict showed a clear tendency to display more internalising problems. Various studies indicate that the decisive factor in the psychological adjustment of children is the way in which their parents interact following the split (Fariña, Parada, Novo, \& Seijo, 2017; Gerard, Krishnakumar, \& Buehler, 2006), with a higher exposure to disputes, denigration and recriminations between their parents causing greater externalising and internalising problems in children (Block, Block, \& Morrison, 1981; De la Torre, 2005; Hetherington, 1999). In this regard, numerous authors note that the intensity of post-divorce interparental conflict is the most influential factor in family relationships and in the frequency of visits to the non-custodial parent (Amato, 2000; De la Torre, 2005; Morgado, 2010; Moura, Andrade, Rocha, \& Mena, 2010; Pinheiro, 2014).

As mentioned previously, another variable of interest besides the intensity of post-divorce conflict is the practice or absence of coparenting following the break-up of the couple. In relation to this last variable, as anticipated in Hypothesis 3, the results show a highernumber of minors affected emotionally, behaviourally and educationally (sadness and crying, low self-esteem, anxiety, anger, aggression, disobedience, self-harm and poor academic performance) when coparenting is not practised between parents in comparison to when this practice is present. This data coincides with studies which indicate that the involvement of both parents in the different areas of the lives of their children is strongly linked to good academic, social, emotional and behavioural adjustment
(Adamsons \& Johnston, 2013; Morgado, 2010). Prior research has shown the importance of postdivorce coparenting for the adaptation of both children and parents to the break-up (Cowan, Cowan, Pruett, \& Pruett, 2007; Yárnoz-Yaben, 2010), although the study by Yárnoz-Yaben et al. (2012) did not find a significant relationship between willingness to coparent among parents and behavioural problems in children. However, Musitu, Martínez, \& Murgui (2006) indicate that the support of both father and mother has a positive impact on the social self-esteem of adolescents and on their academic adjustment. Some authors suggest that in order for quality coparenting to take place, parents must have adapted adequately to the divorce, and have become aware of their identity as coparents (Markham et al., 2007; Yánoz-Yaben, 2010). For this reason, as Martiñón et al. (2017) point out, it is important that interventions aimed at protecting and preventing the consequences of divorce for children contribute to the promotion of positive coparenting between parents in situations of relationship breakdown of couples with children.

In conclusion, in line with previous research, the results corroborate the fact that post-divorce conflict acts as a predictor of the presence of emotional, behavioural and educational problems in children (Arch, 2010; Cummings \& Davies, 2010; López-Larrosa, 2009). However, Hypothesis 4 is only partially confirmed, as it has been found that it is not only custody conflicts but also those revolving around financial matters, along with a medium or high intensity of conflict, which predict behavioural problems in children. Similarly, a moderate and high intensity of conflict predicts emotional and educational problems among minors. These results coincide with various studies, which indicate that the level and intensity of conflict between parents is the most influential factor in the post-divorce adjustment of children (Mitcham-Smith \& Henry, 2007).

As such, in light of the results obtained, it may be concluded that the effects of divorce on children are determined by the type and intensity of conflict between parents, as well as by the practice of coparenting. It would also be relevant to consider the way in which these conflicts are 
managed, and this should be taken into account in future research. Moreover, it is necessary to explore further those variables that are related to the willingness to coparent following divorce (Yárnoz-Yaben, 2010). As stated by Kelly \& Emery (2003), the most important factor determining the impact of divorce on a child is the way in which the parents emotionally manage their split, depending upon whether or not they maintain strong cooperation as parents and how they help or hinder their children in the process, both when informing their children of their decision as well as throughout the later family readjustment. Although destructive parental conflict diverts children's attention and leads to ineffective parenting, which can create severe dysfunctionality in the family (Cutrín et al., 2017; Gerard et al., 2006), positive and constructive management of interparental conflict may even enhance feelings of security in children and wellbeing in the family (Zemp et al., 2016).

Moreover, it is necessary to mention several limitations to this study. Firstly, the psychosocial variables analysed were evaluated by the Psychosocial Team of the Family Meeting Point, which constituted the only source of information as the study was based on the review of case files. However, it is important to note that these evaluations are the product of an agreement between at least two members of staff. Moreover, although the available information about the intensity of the conflict refers to the number of judicial proceeding against the expartner, it would be recommendable to include more aspects that could influence this variable, such as the level of negative affection expressed by parents and how the express it. In addition, future studies should analyse in a deeper way the consequences of separation/divorce on children examining differences according their age and gender. Finally, the study is based on cross-sectional data, which does not allow causal relationships to be established between the variables under study. In this sense, longitudinal studies are required which are also able to reflect variations in the post-divorce dynamics of the family group.

Despite this, we consider this study to contribute relevant data on the importance of post-divorce dynamics, and more specifically, on the role of the type and intensity of postdivorce conflict between parents and its psychoemotional, behavioural and academic impact on minors. This represents an approach that may help to produce the change required in the way in which society views divorce. The relationship between divorce and problems in children is more complex than has long been believed (Yárnoz-Yaben et al., 2012). Although it is currently known that the majority of children adapt well to their parents' divorce (Amato, 2000), other studies such as that of Kelly \& Emery (2003) show that parents' adaptation to divorce largely conditions their children's adaptation. Post-divorce conflict may be considered to be the main factor that negatively affects adaptation in both children and parents. For this reason, it is necessary to implement prevention and intervention programmes to work with families displaying moderate/high levels of post-divorce conflict to ensure that the parents adequately manage the conflicts that are present. As indicated by Zemp et al. (2016), these programmes must include not only the development of parental skills with the aim of improving parent-child relationships and child adjustment, but also the improvement of interparental relationships to enhance the wellbeing of the whole family. In this respect, the figure of Parenting Coordinator (Fariña et al., 2017) is of special interest, as a professional specialized in this type of cases with high levels of conflict.

\section{- Acknowledgments}

The authors wish to give their appreciation to the General Direction of Gender Violence and Victims Assistance of the Junta de Andalucía for the collaboration and to the Justice Service and the Family Meeting Point of Jaén for help in this study.

\section{- Conflict of interest}

The authors declare no conflict of interest.

\section{REFERENCES}

Adamsons, K., \& Johnson, S. K. (2013). An updated and expanded meta-analysis of nonresident fathering and child well-being. Journal of Family Psychology, 27, 589-599. https://doi.org/10.1037/a0033786 
Amato, P. R. (2000). The consequences of divorce for adults and children. Journal of Marriage and Family, 62, 1269-1287. https://doi. org/10.1111/i.1741-3737.2000.01269.x

Amato, P. R. (2010). Research on divorce: Continuing trends and new developments. Journal of Marriage and Family, 72, 650$666 . \quad$ https://doi.org/10.1111/i.17413737.2010.00723.x

Arce, R., Fariña, F., \& Seijo, D. (2005). Razonamientos judiciales en procesos de separación: Análisis cognitivo y de contenido de las motivaciones [Judicial reasoning in parental separation and divorce proceedings: Content and cognitive analysis of judicial reasoning]. Psicothema, 17(1), 57-63. Retrived from http:// www.psicothema.com/pdf/3064.pdf

Arch, M. (2010). Divorcio conflictivo y consecuencias en los hijos: implicaciones para las recomendaciones de guarda y custodia [High conflictive divorce and its consequences on children: Implications and recommendations about custody arrangements]. Papeles del Psicólogo, 31, 183-190. Retreived from http:// www.papelesdelpsicologo.es/pdf/1845.pdf

Arkes, J. (2015). The temporal effects of divorces and separations on children's academic achievement and problem behavior. Journal of Divorce \& Remarriage, 56, 25-42. https://doi. org/10.1080/10502556.2014.972204

Bacon, B. L., \& McKenzie, B. (2004). Parent education after separation-divorce. Impact of the level of parental conflict on outcomes. Family Court Review, 42, 85- 98. https://doi. org/10.1111/i.174-1617.2004.tb00635.x

Bonach, K. (2005). Factors contributing to quality coparenting: Implications for family policy. Journal of Divorce \& Remarriage, 43, 79-103 https://doi.org/10.1300/J087v43n03 05

Block, J. H., Block, J., \& Morrison, A. (1981). Parental agreement-disagreement on child rearing orientations and gender-related personality correlates in children. Child Development, 52, 965-974. http://dx.doi. org/10.2307/1129101

Braver, S. L., Shapiro, J. R., \& Goodman, M. R. (2006). Consequences of divorce for parents. In M. A. Fine \& J. H. Harvey (Eds.), Handbook of divorce and relationship dissolution (pp. 313337). Mahwah, NJ: LEA.

Cheng, J., \& George, R. A. (2005). Cultivating resilience in children from divorce families. The Family Journal: Counseling and Therapy or Couples and Families, 13, 452-455. https:// doi.org/10.1177\%2F1066480705278686

Choi, J. K., \&Pyun, H. S. (2014). Nonresidentfathers' financial support, informal instrumental support, mothers' parenting, and child development in single mother families with low income. Journal of Family Issues, 35, 526-546. http://dx.doi. org/10.1177/0192513X13478403

Contreras L., \& Cano-Lozano, M. C. (2016). Childto-parent violence: The role of exposure to violence and its relationship to social-cognitive processing. The European Journal of Psychology Applied to Legal Context, 8, 43-50. http:// dx.doi.org/10.1016/i.ejpal.2016.03.003

Corrás, T., Seijo, D., Fariña, F., Novo, M., Arce, R., \& Cabanach, R. G. (2017). What and how much do children lose in academic settings owing to parental separation? Frontiers in Psychology, 8, 1545. http://doi.org/10.3389/ fpsyg.2017.01545

Cowan, C. P., Cowan, P. A., Pruett, M. K., \& Pruett, K. (2007). An approach to preventing coparenting conflict and divorce in low-income families: Strengthening couple relationships and fostering fathers' involvement. Family Process, 46, 109-121. https://doi.org/10.1111/ j.1545-5300.2006.00195.x

Cummings, E. M., \& Davies, P. T. (2010). Marital conflict and children: An emotional security perspective. New York: The Guilford Press.

Cutrín, O., Gómez-Fraguela, J. A., Maneiro, L., \& Sobral, J. (2017). Effects of parenting practices through deviant peers on nonviolent and violent antisocial behaviours in middle-and lateadolescence. European Journal of Psychology Applied to Legal Context, 9(2), 75-82. https:// doi.org/10.1016/i.ejpal.2017.02.001

Davies, P. T., Harold, G. T., Goeke-Morey, M. C., Cummings, E. M., Shelton, K., \& Rasi, J. A. (2002). Child responses to interparental conflict: Comparing the relative roles of emotional security and social learning processes. Monographs of the Society for Research in Child Development, 
67, 27-40. https://doi.org/10.1111/1540$\underline{5834.00207}$

De La Torre, J. L. (2005). Las relaciones entre padres e hijos después de las separaciones conflictivas [Parents-children relationships after conflictive separations]. Apuntes de Psicología, 23, 101-112. Retreived from http://www. apuntesdepsicologia.es/index.php/revista/ article/download/83/85

Dudak, A. (2013). Fathers claiming custody of their children - clients of psychological and legal counselling. Procedia Social and Behavioral Sciences, 84, 1281-1285. https:// doi.org/10.1016/J.SBSPRO.2013.06.744

Eurostat (2017). Marriage and divorce statistics. Retrieved from http://ec.europa.eu/eurostat/ statistics-explained/index.php/Marriage_and divorce statistics

Fagan, F. P., \& Churchill, A. (2012). The effects of divorce on children. Marriage \& Religion Research Institute. Retrieved from http:// downloads.frc.org/EF/EF12A22.pdf

Fariña, F., Parada, V., Novo, M., \& Seijo, D. (2017). El Coordinador de Parentalidad: Un análisis de las resoluciones judiciales en España [Parenting Coordinator: An Analysis of Spanish Judicial Reasoning]. Acción Psicológica, 12(2), $157-$ 170. https://doi.org/10.5944/ap. 14.2.21346

Galatzer-Levy, R. M. \& Kraus, L. (1999). The scientific basis of child custody decisions. New York: Wiley.

García, T., \& Solsona, M. (2011). El divorcio como nudo biográfico. Una revisión de la literatura reciente desde la perspectiva de la vulnerabilidad postdivorcio [The divorce as a biographic nude. A review of recent literature from the postdivorce vulnerability approach]. Documents d'Anàlisi Geogràfica, 57, 105126. Retrieved from https://ddd.uab.cat/pub/ dag/02121573v57n1/02121573v57n1p105. pdf

Gerard, J. M., Krishnakumar, A., \& Buehler, C. (2006). Marital conflict, parent-child relations, and youth maladjustment: a longitudinal investigation of spillover effects. Journal of Family Issues, 27, 951-975. https://doi. org/10.1177/0192513X05286020

Guillén, N., Roth, E., Alfaro, A., \& Fernández,
E. (2015). Youth alcohol drinking behaviour: Associated risk and protective factors. Revista Iberoamericana de Psicología y Salud, 6, 53-63. https://doi.org/10.1016/i.rips.2015.03.001

Hetherington, E. M. (1999). Should we stay together for the sake of the children? In E. M. Hetherington (Ed.), Coping with divorce, single parenting, and remarriage. A risk and resiliency perspective (pp. 93-116). Mahwah, NJ: LEA.

Hopper, J. (2001). The symbolic origins of conflict in divorce. Journal of Marriage and Family, 63, 430-445. $\quad$ https://doi.org/10.1111/i.17413737.2001.00430.x

Kelly, J. B. (2003). Changing perspectives on children's adjustment following divorce. A view from the United States. Childhood, 10, 237-254. https://doi. org/10.1177\%2F0907568203010002008

Kelly, J. B., \& Emery, R. E. (2003). Children's adjustment following divorce: Risk and resiliency perspectives. Family Relations, 52, 352-362. https://doi.org/10.1111/i.17413729.2003.00352.x

Landsford, J.E. (2009). Parental divorce and children's adjustment. Perspectives on Psychological Science, 4, 141 -152. https://doi. org/10.1111/i.1745-6924.2009.01114.x

López-Larrosa, S. (2009). El sistema familiar ante el divorcio: factores de riesgo y protección y programas de intervención [Family system in divorce: risk and protective factors and intervention programs]. Cultura y Educación, 21, 391-402. https://doi. org/10.1174/1 13564009790002436

López-Larrosa, S., Sánchez-Souto, V., \& Mendiri, P. (2012). Los adolescentes y el conflicto interparental destructivo: impacto en la percepción del sistema familiar y diferencias según el tipo de familia, la edad y el sexo de los adolescentes [Adolescents and destructive interparental conflict: Impact on the perception of the family system and differences by adolescents' type of family, age and sex]. Universitas Psychologica, 11, 1255-1262. Retreived from http://revistas.javeriana.edu.co/ index.php/revPsycho/article/view/1255

Madden-Derdich, D. A., \& Leonard, S. A. (2000). Parental role identity and fathers' involvement 
in coparental interaction after divorce: fathers' perspectives. Family Relations, 49, 311-318. https://doi.org/10.1111/i.1741$3729.2000 .00311 . x$

Madden-Derdich, D. A., Leonard, S. A., \& Christopher, F. S. (1999). Boundary ambiguity and coparental conflict after divorce: An empirical test of a family systems model of the divorce process. Journal of Marriage and the Family, 61, 588-598. https://doi. org/10.2307/353562

Markham, M. S., \& Coleman, M. (2012). The good, the bad, and the ugly: divorced mothers' experiences with coparenting. Family Relations, 61, 586-600. https://doi.org/10.1111/ j.1741-3729.2012.00718.x

Markham, M. S., Ganong, L. H., \& Coleman, M. (2007). Coparental identity and mothers' cooperation in coparental relationships. Family Relations, 56, 369-377. https://doi. org/10.1111/i.1741-3729.2007.00466.x

Martiñón, J. M., Fariña, F., Corrás, T., Seijo, D., Souto, A., \& Novo, M. (2017). Impacto de la ruptura de los progenitores en el estado de salud física de los hijos [Impact of family breakup on the physical health of children]. European Journal of Education and Psychology, 10, 9-14. http://dx.doi.org/10.1016/i. ejeps.2016.10.002

Mclntosh, J., \& Long, J. (2005). Current findings in Australian children in postseparation disputes: Outer conflict, Inner discord. Journal of Family Studies, 11, 99-109. https://doi. org/10.5172/ifs.327.11.1.99

Mitcham-Smith, M., \& Henry, W. J. (2007). Highconflictdivorcesolutions: parenting coordination as an innovative co-parenting intervention. The Family Journal, 15, 368-373. https://doi. org/10.1177/1066480707303751

Montero, I., \& León, O. G. (2007). A guide for naming research studies in Psychology. International Journal of Clinical and Health Psychology, 8, 693-703. Retreived from http:// www.aepc.es/iichp/GNEIP07 es.pdf

Morgado, B. (2008). Experiencia del divorcio parentaly ajuste psicológico infantil [Experience of parental divorce and children psychological adjustment]. (Doctoral thesis, University of
Sevilla, Faculty of Psychology, Spain). Retreived from https://idus.us.es/xmlui/bitstream/ handle/11441/15479/Y TD PS-PROV5. pdf? sequence $=-1$ \&isAllowed $=y$

Morgado, B. (2010). La relación con el padre tras el divorcio: la mirada de niños y niñas [Relationship with noncustodial father after divorce: children's points of view]. Estudios de Psicología, 31, 39-59. https://doi. org/10.1174/021093910790744554

Moura, O., Andrade, R., Rocha, M., \& Mena, P. (2010). Children's Perception of Interparental Conflict Scale (CPIC): Factor structure and invariance across adolescents and emerging adults. International Journal of Testing, 10, 364-382. https://doi.org/10.1080/1530505 8.2010 .487964

Musitu, G., Martínez, B., \& Murgui, S. (2006). Conflicto marital, apoyo parental y ajuste escolar en adolescentes [Marital conflict, parents support and scholar adjustment in adolescents]. Anuario de Psicología, 37, 247 258. Retreived from http://www.redalyc.org/ articulo.oa?id $=97012834003$

Overbeek, G., Vollebergh, W., De Graaf, R., Schulte, R., De Kemp, R., \& Engels, R. (2006). Longitudinal associations of marital quality and marital dissolution with the incidente of DSMIII-R disorders. Journal of Family Psychology, 20, 284-291. https://doi.org/10.1037/08933200.20.2.284

Pinheiro, C. (2014). Relación parental, autoestima y sintomatología depresiva en jóvenes adultos. Implicaciones de los conflictos interparentales, coalición y triangulación [Parental relationship, self-esteem and depressive symptomatology in young adults]. Universitas Psychologica, 13, 15-29 https://doi.org/10.11144/Javeriana. UPSY13-3.rpas

Rappaport, S. R. (2013). Deconstructing the impact of divorce on children. Family Law Quarterly, 47, 353-377. Retreived from https://www.jstor. org/stable/24576133? seq=1 \#page_scan tab_contents

Seijo, D., Fariña, F., Corrás, T., Novo, M., \& Arce, R. (2016). Estimating the epidemiology and quantifying the damages of parental separation in children and adolescents. Frontiers in 
Psychology, 7, 1-9. https://doi.org/10.3389/ fpsyg.2016.01611

Yárnoz-Yaben, S. (2010). Hacia la coparentalidad post-divorcio: percepción del apoyo de la ex pareja en progenitores divorciados españoles [Towards the postdivorce coparenting: perception of the support from the ex-partner in Spanish divorced parents]. International Journal of Clinical and Health Psychology, 10, 295-307. Retreived from http://www.aepc.es/ iïchp/articulos_pdf/iichp-352.pdf

Yárnoz-Yaben, S. (2013). Perdón y divorcio: Una perspectiva clínica [Forgiveness and divorce: A clinical perspective]. Clínica Contemporánea, 4, 211-221. https://doi.org/10.5093/ $\underline{\mathrm{cc} 2013 \mathrm{a} 17}$
Yárnoz-Yaben, S., Comino, P., \& Garmendia, A. (2012). Ajuste al divorcio de los progenitores y problemas de conducta en hijos de familias separadas [Parental adjustment to divorce and behaviour problems in children from divorced families]. Infancia y aprendizaje, 35, 37-48. http://dx.doi. org/10.1174/021037012798977485

Zemp, M., Bodenmann, G., \& Cummings, E. M. (2016). The significance of interparental conflict for children. Rationale for couplefocused programs in family therapy. European Psychologist, 21, 99-108. hittps://doi. org/10.1027/1016-9040/a000245 